\title{
Patterns in tintinnid species composition and abundance in relation to hydrological conditions of the southwestern Atlantic during austral spring
}

\author{
Gustavo A. Thompson ${ }^{1, *}$, Viviana A. Alder ${ }^{1,2,3}$ \\ ${ }^{1}$ Departamento de Ecología, Genética y Evolución, Facultad de Ciencias Exactas y Naturales, Universidad de Buenos Aires, \\ C1428EHA Buenos Aires, Argentina \\ ${ }^{2}$ Consejo Nacional de Investigaciones Científicas y Técnicas, Avenida Rivadavia 1917, C1033AAJ Buenos Aires, Argentina \\ ${ }^{3}$ Instituto Antártico Argentino, Cerrito 1248, C1010AAZ Buenos Aires, Argentina
}

\begin{abstract}
The tintinnid community was assessed on a collection of 42 samples taken at depths of $5,10,25$ and $50 \mathrm{~m}$ from 17 oceanographic stations located along 34 to $62^{\circ} \mathrm{S}, 51$ to $57^{\circ} \mathrm{W}$, in November 1995. Samples were collected by means of a Niskin bottle cast, and reverse-filtered through a $10 \mu \mathrm{m}$ mesh filter. A total of 60 tintinnid taxa were recorded, most of which with a distribution circumscribed to Antarctic, Subantarctic or Brazil-Malvinas Confluence waters, thus allowing the distinction of Antarctic, Subantarctic and Transitional biogeographic zones, respectively. A comparison based on the analysis of Niskin bottle versus flowmetered $35 \mu \mathrm{m}$ mesh net paired samples indicated that absolute abundances of tintinnid species with diameters $>40 \mu \mathrm{m}$ almost did not differ between collecting methods. Tintinnid abundances and species structure reflected the degree of variability in the hydrological conditions of the southwestern Atlantic between 1994 and 1995. Sea surface temperature fluctuations within Brazil-Malvinas Confluence waters involved pronounced changes in the tintinnid communities of the Transition Zone: the increase of southward warm water transport during 1994 favoured the dominance of subtropical species along the ecotone, while its decrease during 1995 favoured the contribution of subantarctic species. Low hydrological variability in the Subantarctic and Antarctic Zones was reflected in a quite similar tintinnid community structure during these 2 years. Acanthostomella norvegica forma typica and Cymatocylis antarctica forma typica in the Subantarctic Zone, and Codonellopsis gaussi and Cymatocylis convallaria in the Antarctic Zone, might be regarded as key tintinnid species, based on their persistence and dominance.
\end{abstract}

KEY WORDS: Tintinnid $\cdot$ Biogeography $\cdot$ Key species $\cdot$ Brazil-Malvinas Confluence $\cdot$ Southwestern Atlantic

Resale or republication not permitted without written consent of the publisher

\section{INTRODUCTION}

Tintinnids (loricate ciliates ranging in size from 15-20 to 200-300 $\mu \mathrm{m}$ ) play different significant ecological roles within microbial communities (Pierce \& Turner 1992, 1994), and have been described as useful tools in biogeographic studies and as indicators of hydrological circulation (Taniguchi 1983, Zeitzschel 1990, Pierce \& Turner 1993, Alder \& Thompson 2000, Thompson 2001). Most studies on tintinnid assemblages, however, have been performed in coastal loca- tions and were focused on their fluctuations (species composition, abundance) at seasonal scales in relation to environmental factors, such as food availability, mesozooplankton grazing pressure and physico-chemical variables (Abboud-Abi Saab 1989, Kamiyama \& Tsujino 1996, Godhantaraman 2002, Modigh \& Castaldo 2002, Urrutxurtu 2004). Knowledge of species structure and their distributional patterns over a regional scale, helps to understand ecosystem dynamics in terms of environmental stability, habitat heterogeneity, productivity and interspecific interactions 
(Tilman 1999, Gaston 2000). In this context, temporal mesoscale changes in the biogeographic patterns of tintinnid taxocoenosis should reflect shifts in the location of water masses, oceanic currents and frontal zones. Such tintinnid-based analyses have been less common and mainly restricted to the North Atlantic and North Sea (Zeitzschel 1966, Lindley 1975).

The southwestern Atlantic Ocean is a hydrologically complex area occupied at its southernmost section by the cold waters of the Antarctic Circumpolar Current (ACC). At the Polar Front (located between 55 and $58^{\circ} \mathrm{S}$, depending on longitude and season; Ikeda et al. 1989), Antarctic waters sink under the less dense Subantarctic Surface waters and run northward. North to the Drake Passage, part of the ACC branches off as the Malvinas Current, running northeast over the continental slope, and turning to the east at approximately $39^{\circ} \mathrm{S}$ (Legeckis \& Gordon 1982, Olson et al. 1988). The Subtropical Front ( 48 to $50^{\circ} \mathrm{S}$ ) represents the northern limit of purely subantarctic waters from the Malvinas Current and the beginning of the Brazil-Malvinas Confluence (BMC) (Peterson \& Stramma 1991). In this ample region, subantarctic waters (Malvinas Current), subtropical waters (Brazil Current) and waters of the South Atlantic Drift mix horizontally and vertically, engendering isolated cells and tongues of pure subantarctic or subtropical waters (Witter \& Gordon 1999, Willson \& Rees 2000). Also, freshwater influence from the Río de la Plata can be detected in the area (Provost et al. 1995). The BMC shows one of the world's largest annual variability in sea surface height signals, in contrast with the ACC (Chelton et al. 1990) and, in particular, with the area between $\sim 55$ and $48^{\circ} \mathrm{S}$, characterised by a local minimum of variability (Fu 1996). Such strong variability has been related to the intense meandering and eddy shedding of this zone (Garzoli \& Garraffo 1989, Fu 1996, Witter \& Gordon 1999).

The BMC has been the main subject of many research programs focusing on the influence of Atlantic Ocean circulation and sea surface temperature (SST) on the low-frequency changes of the local climate (Goni et al. 1996, Boebel et al. 1999, Witter \& Gordon 1999, Willson \& Rees 2000). Previous mesoscale studies on the BMC and adjacent waters have been either focused on environmental factors (Brandini et al. 2000) or on microplankton, but restricted temporally (Boltovskoy et al. 1996, Fernandes 1999, Thompson et al. 1999). Thus, current understanding of the hydrological influences and their temporal fluctuations in terms of ecosystem functioning is still limited and unclear, and mainly only for the BMC Zone.

While taking these aspects into consideration, an important task of the present study was to evaluate how the environmental heterogeneity (in particular, the hydrological conditions of the BMC and adjacent
Subantarctic and Antarctic waters) could influence tintinnid assemblages at a spatial-temporal mesoscale. This was achieved by assessing the absolute abundances and distribution range of tintinnid species $>10 \mu \mathrm{m}$ in the upper $50 \mathrm{~m}$ layer during November 1995, as well as their relation to abiotic and biotic settings. Possible interannual changes in the biological conditions of the area were assessed through comparison of the present data set with that obtained from an overlapping transect made in November 1994 (Thompson et al. 1999).

\section{MATERIALS AND METHODS}

A total of 42 microplankton samples were collected by means of a Niskin bottle cast (bottle sampling method) from 17 oceanographic stations located along 34 and $62^{\circ} \mathrm{S}\left(51\right.$ to $\left.57^{\circ} \mathrm{W}\right)$, in November 1995 (TABIA III cruise; Fig. 1A). Sampling was performed at 4

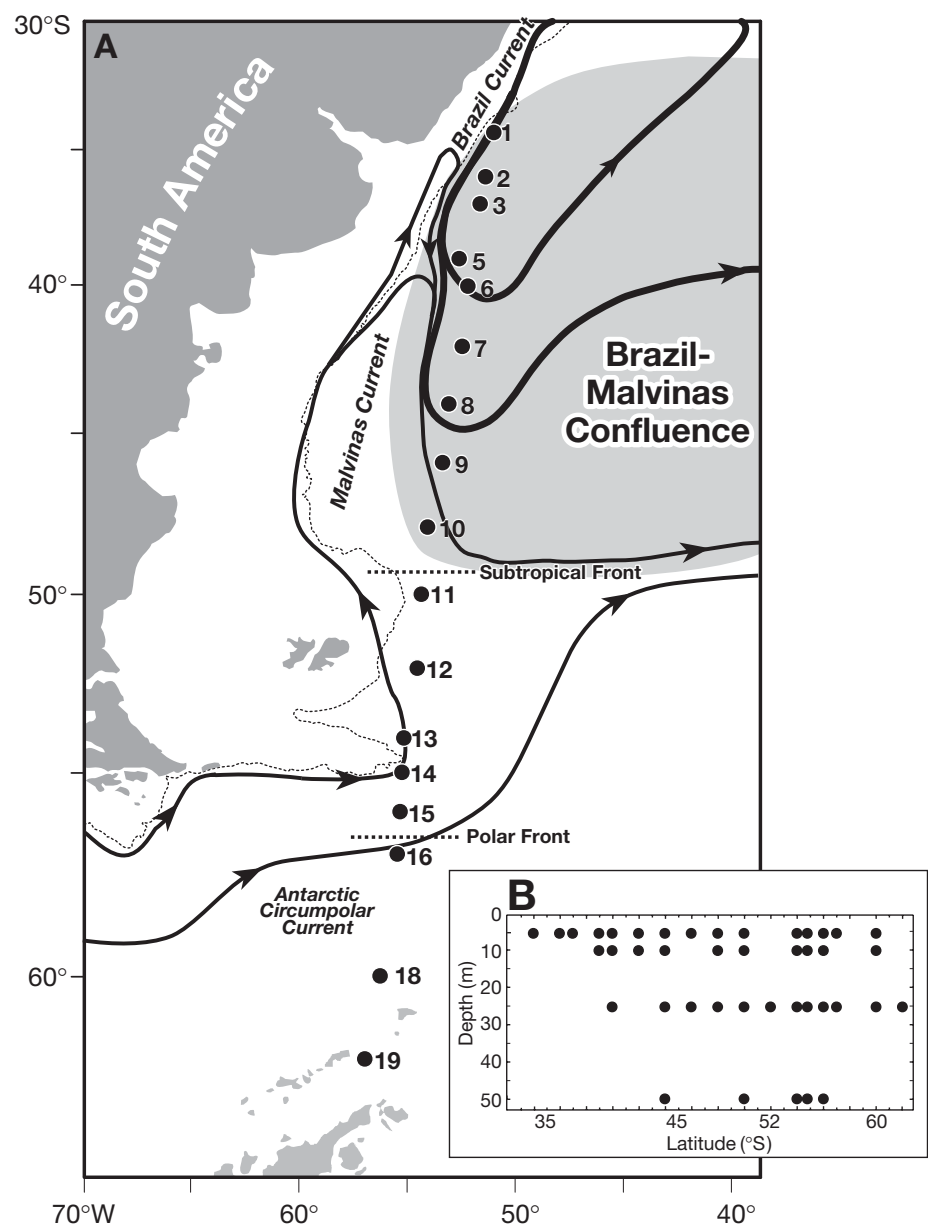

Fig. 1. (A) Geographic location of the stations (no plankton samples for Stns 4 and 17) and general circulation pattern; (B) vertical coverage of plankton samples along the transect 
depths $(5,10,25$ and $50 \mathrm{~m})$, although the vertical coverage at each station was uneven (Fig. 1B). Then, 181 of water per sample were reverse-filtered through a $10 \mu \mathrm{m}$ mesh (Dodson \& Thomas 1978) and preserved with $3 \%$ formaldehyde.

Chlorophyll a concentration was determined at several depths down to $200 \mathrm{~m}$ with $200 \mathrm{ml}$ of water filtered through Whatman GF/C filters at 19 of the stations (Fig. 2). Filters were stored dried and frozen prior to extraction with acetone $90 \%$ and the analysis by fluorometric techniques in the laboratory (Evans \& O'Reilly 1983, Brandini et al. 2000). Samples collected for the analysis of nutrients were prefiltered (GF/C), preserved with $\mathrm{HgCl}_{2}$ and kept frozen until the assessment of their nitrate and phosphate content with a Technicon Autoanalyser (Strickland \& Parsons 1972, Brandini et al. 2000). Vertical profiles of water temperature were obtained from 13 expendable bathythermograph launchings to $460 \mathrm{~m}$. Information on the TOPEX/POSEIDON satellite sea surface height
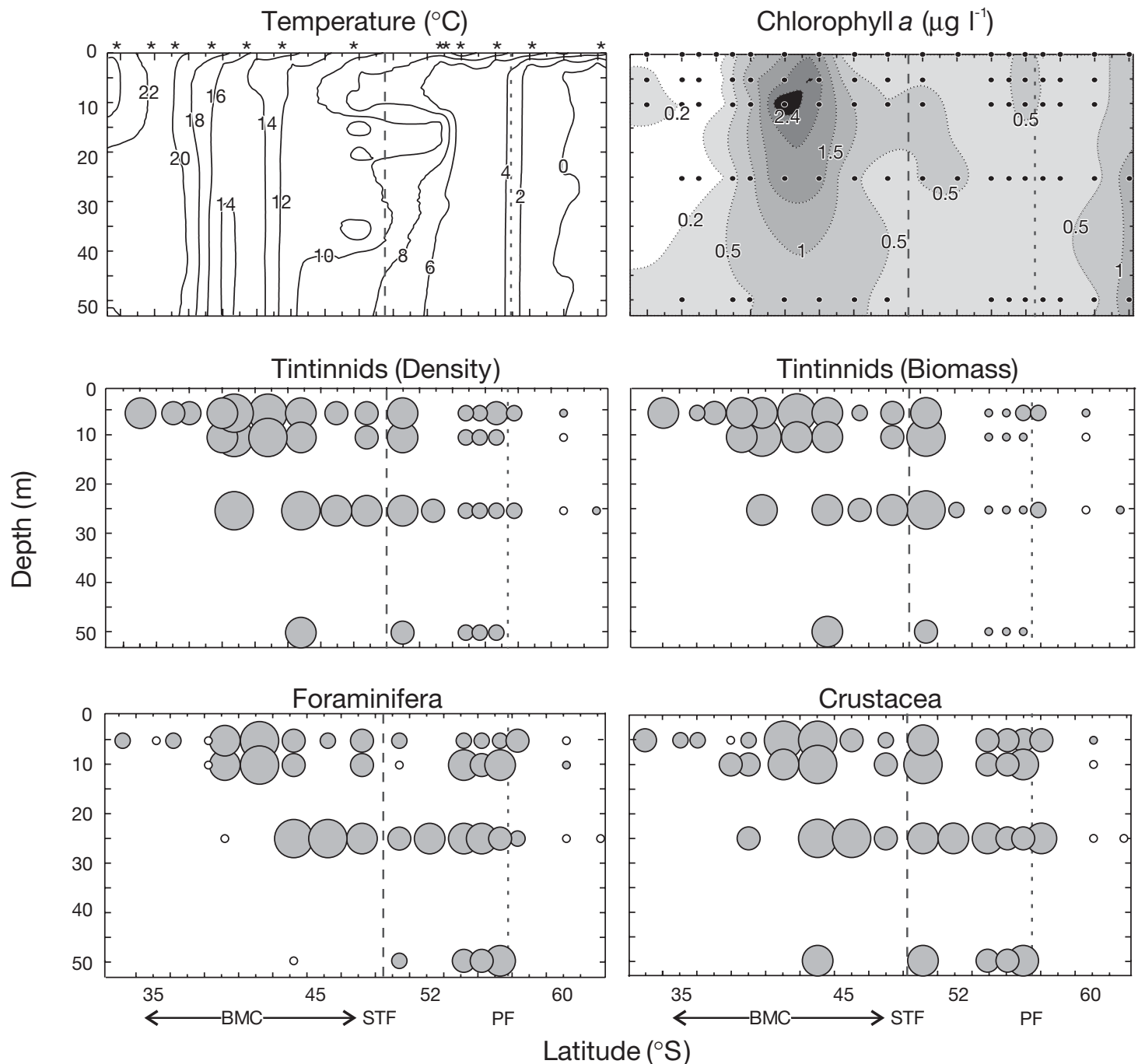

\begin{tabular}{|c|c|c|c|c|c|c|}
\hline & $\circ$ & 。 & 0 & O & & \\
\hline Tintinnids (ind. I $^{-1}$ ) & \multirow{4}{*}{0} & $<1$ & $1-5$ & $5-50$ & $50-200$ & $200-500$ \\
\hline Tintinnids $\left(\mu \mathrm{g} \mathrm{CI^{-1 } )}\right.$ & & $<0.01$ & $0.01-0.05$ & $0.05-0.1$ & $0.1-0.4$ & $0.4-0.7$ \\
\hline Foraminifera (ind I $^{-1}$ ) & & 0.05 & $0.1-0.25$ & $0.25-0.5$ & $0.5-1$ & $1-3$ \\
\hline Crustacea (ind $\mathrm{I}^{-1}$ ) & & 0.05 & $0.1-1$ & $1-5$ & $5-10$ & $10-15$ \\
\hline
\end{tabular}

Fig. 2. Geographic and vertical distributions of temperature (based on 13 XBT launchings, indicated by asterisks), chlorophyll a (dots indicate location of samples), tintinnids, foraminifers and crustacean larvae (BMC: Brazil-Malvinas Confluence; STF: Subtropical Front [approx. location]; PF: Polar Front) 
anomaly for November 1994 and 1995 was obtained from the Colorado Center for Astrodynamics Research website (http://e450.colorado.edu/realtime/gsfc_globalreal-time_ssh/).

Absolute abundances of tintinnids, foraminifers and crustacean larvae (mainly copepods) were estimated by counting 3 subsamples from each sample under an inverted microscope at total magnifications of $200 \times$ or $400 \times$. When the materials were too concentrated in the original samples, up to 6 subsamples were diluted prior to counting. A total of 19560 tintinnid specimens were identified using the classification system proposed by Alder (1999), based on lorica morphology and available information on cytology and ultrastructure of ciliates (Laval-Peuto 1994). Empty tintinnid loricae were not differentiated from those with protoplasm, because mechanical and chemical disturbance associated with collection and fixation procedures has been shown to provoke detachment of the cell from the lorica (Paranjape \& Gold 1982, Alder 1999). Tintinnid biomass was estimated from measurements of the lorica and subsequent conversion to biovolume by assigning various geometrical shapes or combinations thereof. The conversion factor from biovolume to organic carbon proposed by Verity \& Langdon (1984) was applied to the data: pg $\mathrm{C}=\left(\right.$ lorica volume in $\left.\mu^{3}\right) \times 0.053+444.5$.

Tintinnid species diversity was examined analysing the number of species per sample, applying the Shannon-Wiener diversity index (Shannon \& Weaver 1949; ln-based expression) and calculating evenness values (Shannon's measure; Pielou 1969). Correlations of total tintinnid densities with chlorophyll a values, as well as with foraminifer and crustacean larva abundances, and correlations of the concentration of each taxa with chlorophyll a values and SST were calculated by applying the non-parametric Spearman rank order correlation test.

Structural similarities between stations were evaluated through a cluster analysis performed on the basis of the abundances of tintinnid species, using the BrayCurtis coefficient and the unweighted pair-group method with arithmetic averages (UPGMA; Romesburg 1984). In order to avoid bias due to the uneven vertical coverage of the spatial transect (as shown in Fig. 1B), the mean values of density, biomass and diversity for each group of stations derived from the cluster analysis were calculated using the average of each station.

The variables analysed in the present study were also assessed according to a previous study carried out in the area by Thompson et al. during 1994 (1999; TABIA II cruise). Data from the latter investigation, which were obtained from flowmetered $35 \mu \mathrm{m}$ mesh net samples (net sampling method), were re-processed and referred to the 0 to $50 \mathrm{~m}$ layer, in order to perform a comparison with the present data series (1995; bottle sampling method). Possible biases arising from the 2 collecting methods (which are the most commonly applied for the study of tintinnid communities) were evaluated by examining 11 pairs of samples collected simultaneously with these 2 sampling methods in the same area and season. Organisms were counted and species-specific analyses were made following the same procedure as above. For statistical purposes, this comparison was considered a special case of randomised complete blocks design, and a 2-way analysis of variance (ANOVA) design for paired comparisons (Sokal \& Rohlf 1995) was used on 2 occasions: first, to determine differences in total tintinnid abundance between the 2 protocols and, second, to check whether such differences were affected by tintinnid diameters (over or below $40 \mu \mathrm{m}$ ).

\section{RESULTS}

Water temperature ranged between 22 and $-1^{\circ} \mathrm{C}$, and the area surveyed was characterised by a lack of vertical stratification (Fig. 2). Following the criteria of Ikeda et al. (1989), results from the XBT profiles were used to assess the limits of the water masses studied (BMC, Subantarctic and Antarctic waters), as indicated by the location of the Polar Front $\left(\sim 55\right.$ to $57^{\circ} \mathrm{S}$; Fig. 2 ) and the Subtropical Front $\left(\sim 48\right.$ to $50^{\circ} \mathrm{S}$; less precise due to the low density of XBT profiles in the area, Fig. 2). BMC waters ( 34 to $48^{\circ} \mathrm{S}$ ) showed a decrease in SST from 21 to $8^{\circ} \mathrm{C}$. Chlorophyll a concentrations higher than $1 \mathrm{\mu g}^{-1}$ in the upper $25 \mathrm{~m}$ were recorded between 39 and $48^{\circ} \mathrm{S}$, with peaks over $2.4 \mu \mathrm{g} \mathrm{l}^{-1}$ at $10 \mathrm{~m}$ depth between 42 and $44^{\circ} \mathrm{S}$ (Stns 7 and 8; Fig. 2). Subantarctic waters $\left(50\right.$ to $56^{\circ} \mathrm{S}$ ) ranged from 7 to $5^{\circ} \mathrm{C}$, and exhibited the lowest concentrations of chlorophyll a (Fig. 2). In Antarctic waters (south to $57^{\circ} \mathrm{S}$ ), temperatures were around $0^{\circ} \mathrm{C}$, and chlorophyll a concentrations reached values $>1 \mu \mathrm{g} \mathrm{l}^{-1}$ in subsurface waters at $62^{\circ} \mathrm{S}$ (Fig. 2). Nitrate and phosphate concentrations increased southward from the BMC to the Polar Front (from $<4$ to $30 \mu \mathrm{M}$ and from $<1$ to $2.4 \mu \mathrm{M}$ for nitrate and phosphate, respectively).

Tintinnid numbers were generally well correlated with biomass, with mean values of 76 ind. $\mathrm{l}^{-1}$ and $0.14 \mu \mathrm{g} \mathrm{Cl}^{-1}$, and peaks of 500 ind. $\mathrm{l}^{-1}$ and $0.70 \mu \mathrm{g} \mathrm{Cl}^{-1}$ at $10 \mathrm{~m}$ depth at $40^{\circ} \mathrm{S}$ (Fig. 2). Concentrations decreased more with increasing latitude than with increasing depth (ca. 5 to $50 \mathrm{~m}$ ), and dropped to near zero at the southernmost stations located in Antarctic waters (Stns 18 and 19, at 60 to $62^{\circ} \mathrm{S}$; Fig. 2). Foraminifers and crustacean larvae were uniformly distributed in the upper $50 \mathrm{~m}$ north to the Polar Front with mean values of 0.42 and 3.73 ind. $1^{-1}$, respectively (Fig. 2). Foraminifers 
showed a concentration peak of 2.93 ind. $\mathrm{l}^{-1}$ at $42^{\circ} \mathrm{S}$ (5 $\mathrm{m}$ depth), while crustacean larvae peaked at $44^{\circ} \mathrm{S}$ (5 to $25 \mathrm{~m}$ depth), with a concentration of approximately 15 ind. $1^{-1}$ (Fig. 2). Like tintinnids, their densities dropped to near zero in Antarctic waters.

The area under study was characterised by the presence of 23 genera, 43 species and 18 morphotypes (total: 60 taxa). Only a few taxa dominated the tintinnid associations, while most of the species showed low or very low densities (Fig. 3, Appendix 1). Acanthostomella norvegica forma typica was found in Sub- antarctic and BMC waters and was the dominant species in numbers of individuals and biomass (means: 38.78 ind. $\mathrm{l}^{-1}$ and $0.03 \mu \mathrm{g} \mathrm{C} \mathrm{l}^{-1}$; max.: 439.69 ind. $\mathrm{l}^{-1}$ and $0.40 \mu \mathrm{g} \mathrm{C}^{-1}$, respectively). It was followed by Protorhabdonella curta and Cymatocylis antarctica forma typica, present in the BMC and Subantarctic waters, respectively (means: 16.28 and 8.93 ind. $\mathrm{l}^{-1}$; max.: 142.34 and 134.81 ind. $\mathrm{l}^{-1}$, respectively). Despite the similar mean biomass values $\left(0.02 \mu \mathrm{g} \mathrm{C}^{-1}\right)$ shown by the latter 2 taxa, the highest individual biomass value $\left(0.51 \mu \mathrm{g} \mathrm{C}^{-1}\right)$ corresponded to C. antarctica forma typ-

\section{Density (ind. $\mathrm{I}^{-1}$ )}

\section{Biomass $\left(\mu \mathrm{g} \mathrm{C} \mathrm{I}^{-1}\right)$}
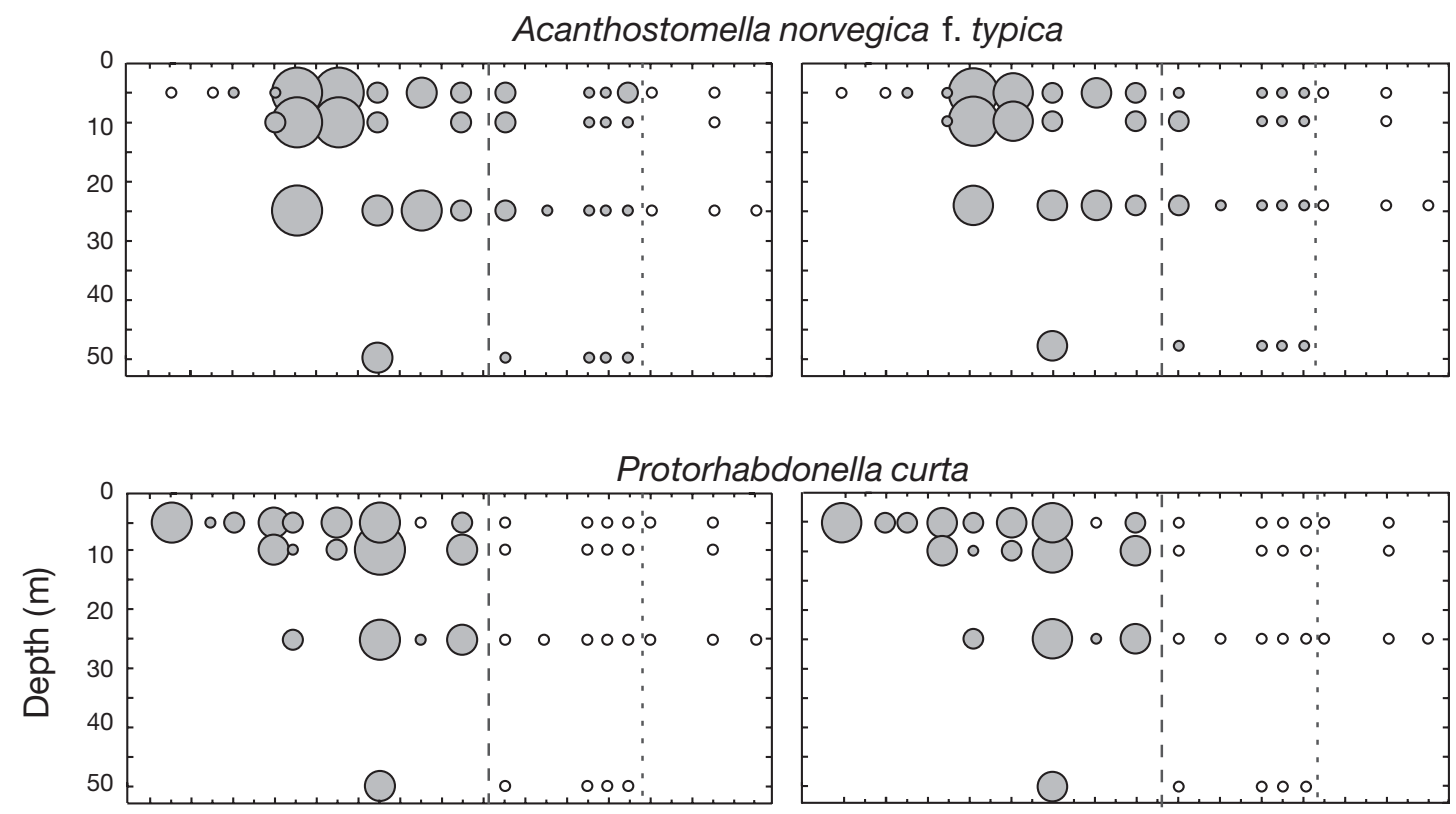

Cymatocylis antarctica f. typica
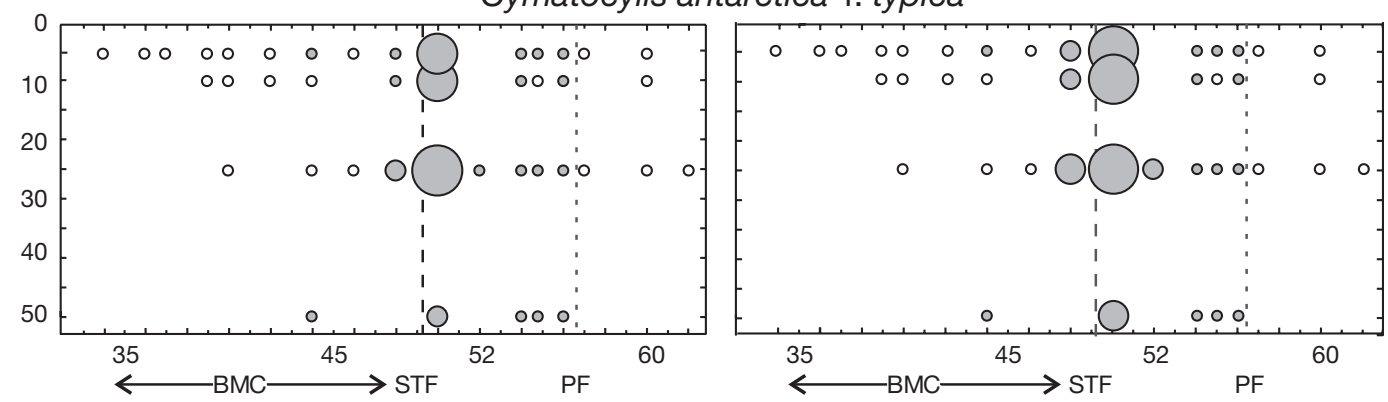

Latitude ( $\left.{ }^{\circ} \mathrm{S}\right)$

\begin{tabular}{|c|c|c|c|c|c|c|}
\hline & $\circ$ & $\circ$ & 0 & 0 & 0 & \\
\hline Dens & \multirow[b]{2}{*}{0} & $<5$ & $5-20$ & $20-55$ & $55-130$ & $>130$ \\
\hline Biomass $\left(\mu \mathrm{g} \mathrm{Cl}^{-1}\right)$ & & $<0.00$ & $.005-0.0$ & $0.025-0$. & $0.1-0.2$ & $>0.2$ \\
\hline
\end{tabular}

Fig. 3. Geographic and vertical distribution of densities and biomass of dominant tintinnid taxa (BMC: Brazil-Malvinas Confluence; STF: Subtropical Front [approx. location]; PF: Polar Front) 
ica. These 3 taxa represented $78 \%$ of the specimens identified $(48,22$ and $8 \%$, respectively) and $60 \%$ of the total tintinnid biomass (26, 17 and $17 \%$, respectively). Steenstrupiella steenstrupii, Amphorides quadrilineata var. minor and Protorhabdonella simplex, also present in the $\mathrm{BMC}$, represented $11 \%$ of the specimens counted and $23 \%$ of the overall tintinnid biomass, with mean values between 0.004 and $0.018 \mu \mathrm{g} \mathrm{C}$ $\mathrm{l}^{-1}$. The remaining $11 \%$ of tintinnid cells (and $17 \%$ of biomass) were distributed among 54 taxa, each of which had mean values $<1$ ind. $\mathrm{l}^{-1}$ and $0.002 \mu \mathrm{g} \mathrm{C} \mathrm{l}^{-1}$ (see Appendix 1).

Tintinnid numbers correlated significantly with chlorophyll a values $\left(\mathrm{r}_{\mathrm{s}}=0.47 \mathrm{p}=0.002\right.$; Spearman rank order correlation test), particularly for Acanthostomella norvegica forma typica and Cymatocylis antarctica forma typica $\left(\mathrm{r}_{\mathrm{s}}=0.64, \mathrm{p}=0.000\right.$ and $\mathrm{r}_{\mathrm{s}}=$ $0.62, \mathrm{p}=0.004$, respectively) within the limits of their distribution range (Figs. 2 \& 3). A. norvegica and Protorhabdonella curta were also found to be correlated with temperature $\left(\mathrm{r}_{\mathrm{s}}=0.72, \mathrm{p}=0.000, \mathrm{~N}=25\right.$ and $\mathrm{r}_{\mathrm{s}}=$ $0.42, \mathrm{p}=0.035, \mathrm{~N}=25$, respectively).

The cluster analysis yielded 3 sharply separated groups of samples (Fig. 4). From north to south, these groups identified the Transition Zone (TZ, Stns 1 to 10; 34 to $48^{\circ} \mathrm{S}$; BMC), the Subantarctic Zone (SZ, Stns 11 to $15 ; 50$ to $56^{\circ} \mathrm{S}$ ) and the Antarctic Zone (AZ, Stns 16 to 19 ; south to $57^{\circ} \mathrm{S}$ ). Boundaries between the zones, which were derived from the cluster analysis, were generally coincident with hydrological limits (Subtropical and Polar Fronts).

The TZ was characterised by the highest concentrations of tintinnids in terms of numbers and biomass

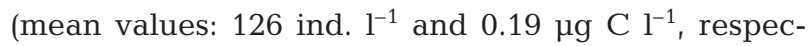
tively), and by a total of 50 taxa with different watermass affinities. A few subantarctic-water tintinnid taxa (Acanthostomella norvegica forma typica, Cymatocylis antarctica forma typica, Codonellopsis pusilla and Steenstrupiella pozzii) were present, whereas warmwater (subtropical) species were more numerous (29), but comprised relatively fewer specimens, chiefly restricted to the northernmost 3 stations (e.g. Ascampbelliella spp., Xystonella spp., Steenstrupiella steenstrupii). Four neritic (e.g. Tintinnopsis spp.), 2 deepwater (Ormosella acantharus: Stn 8, 25 m; Parundella caudata: Stns 2, 6 and 7, 5 to $10 \mathrm{~m}$ ), and 5 cosmopolitan (e.g. Dictyocysta spp. and Amphorides quadrilineata) species occurred occasionally in this zone. Finally, specimens belonging to 6 different genera that could not be identified to the specific level complemented the taxocoenosis of the TZ (see Appendix 1).

The dominant species within the TZ were Acanthostomella norvegica forma typica and Protorhabdonella curta, with mean density values of 66 and 31 ind. $\mathrm{l}^{-1}$, respectively, and little overlap between their distribu- tion zones (Fig. 4). These 2 species accounted for $76 \%$ of the total numbers, and over $52 \%$ of total tintinnid biomass within the TZ. Both the large number of taxa present and their uneven contribution to total tintinnids are reflected in the highest mean diversity values registered for the entire study area (specific richness: 12.1; specific diversity: 1.20). In addition, peaks in the relative numbers of $A$. norvegica forma typica caused isolated specific diversity and evenness drops (e.g. at 40 and $46^{\circ}$ S, Figs. $3 \& 4$ ), which accounted for both the highest and some of the lowest diversity values being recorded for the BMC (Fig. 4).

On the other hand, tintinnid densities in the SZ were moderate, with mean values of 23 ind. $1^{-1}$ and $0.08 \mu \mathrm{g} \mathrm{C}$ $\mathrm{l}^{-1}$. The tintinnid assemblage comprised a total of 12 species typical of subantarctic waters (see Appendix 1). It was dominated by Cymatocylis antarctica forma typica (mean: 19 ind. $\mathrm{l}^{-1}$ ), followed by Acanthostomella norvegica forma typica ( 4 ind. $\mathrm{l}^{-1}$ ). These 2 taxa represented $98 \%$ of total tintinnid cells (82 and 16\%, respectively) and over $97 \%$ (93 and $4 \%$, respectively) of total tintinnid biomass within the SZ, which accounted for the lowest specific richness and diversity values of the study area (means: 3.7 and 0.59, respectively; Fig. 4). The southernmost sector of the SZ, north to the Polar Front, was found to bear a mixture of species with distinct water-type preferences (warm water: Dadayiella ganymedes, Stn 14; antarctic water: Codonellopsis gaussi, Stns 12, 13; deep water: Ormosella acantharus, Parundella caudata, Stns 13, 15).

Finally, the AZ was characterised by the lowest abundance and biomass values (3.5 ind. $\mathrm{l}^{-1}$ and $0.04 \mu \mathrm{g} \mathrm{C} \mathrm{l}^{-1}$, respectively). Tintinnids were typical antarctic species belonging to the genera Laackmanniella, Codonellopsis and Cymatocylis (see Appendix 1). Mean specific richness and diversity values in the AZ (4.5 and 0.87, respectively) were slightly higher than in the SZ (Fig. 4).

The first 2-way ANOVA for paired comparisons applied to the bottle and net sampling methods indicated that estimates of tintinnid abundance were significantly higher for the former: $F=11.06, p=0.007$. A total of 29 out of the 49 taxa registered were detected by both sampling methods; 5 of the remaining 20 taxa were present only in net samples with densities $<0.05$ ind $\mathrm{l}^{-1}$ (the detection limit of bottle sample: 1 ind. in 18 l), thus indicating that the bottle sampling method underestimated up to $10 \%$ of the total number of species present when compared to the net sampling method. The second 2-way ANOVA for paired comparisons, which tested for the absolute abundances of the 29 taxa in common, indicated that differences were not significant $(F=2.43, \mathrm{p}=0.130)$ for the group of species with a diameter $>40 \mu \mathrm{m}(\mathrm{N}=11)$. These taxa were around $13 \%$ more abundant in bottle than in net sam- 


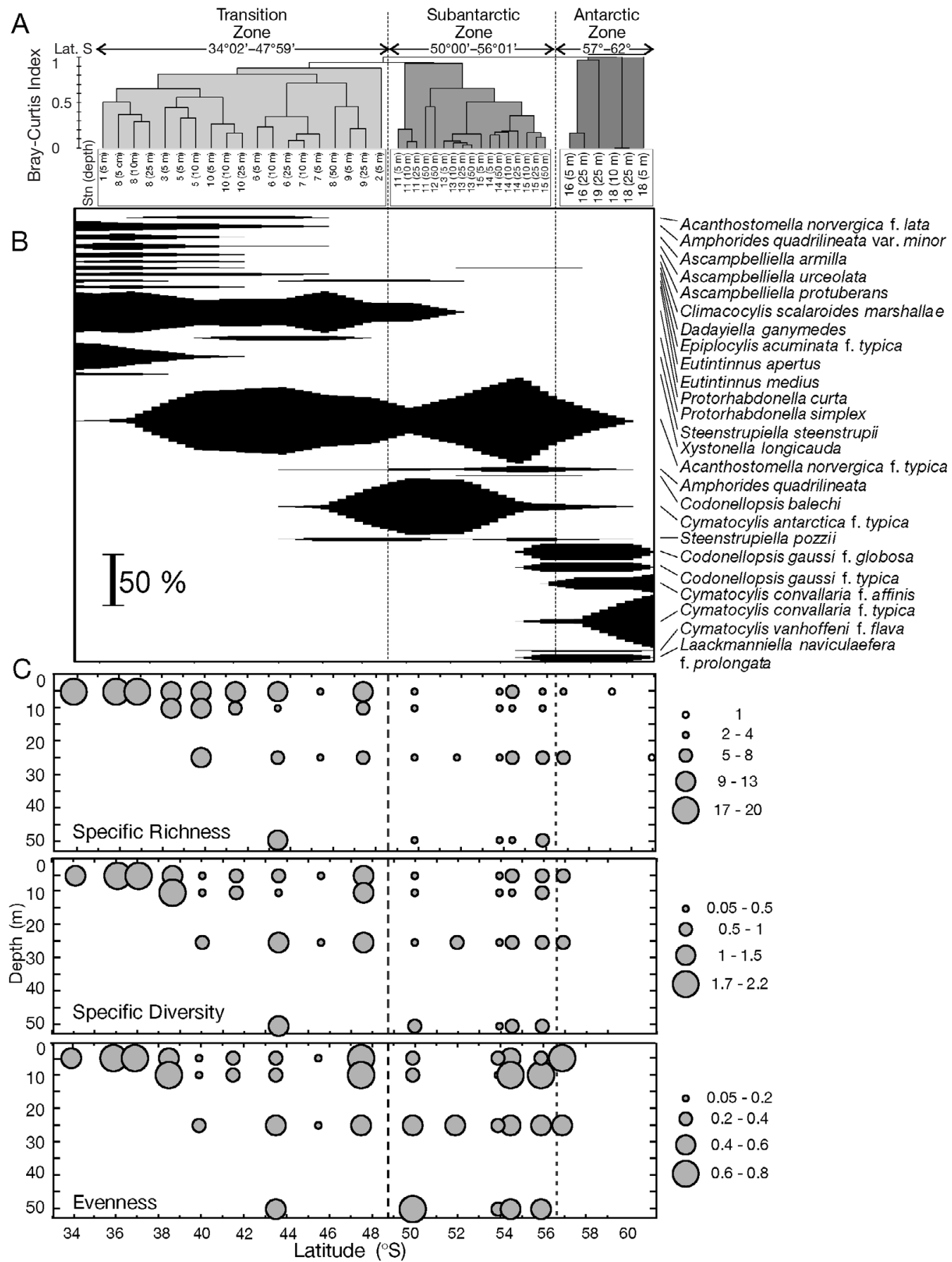

Fig. 4. (A) Biogeographic zones along the transect surveyed as defined by a cluster analysis based on percent of abundance of tintinnid taxa (unidentified excluded; Bray-Curtis coefficient of faunal similarity and UPGMA clustering method). (B) Latitudinal distribution of relative abundance of selected tintinnid taxa along the transect (pooled data for all the available depths).

(C) Geographic and vertical distribution of tintinnid diversity parameters

ples. On the other hand, the effect of the sampling method proved to be highly significant for the group of taxa with a diameter $<40 \mu \mathrm{m}(F=27.67, \mathrm{p}=0.000, \mathrm{~N}=$ 18): for instance, Acanthostomella norvegica forma typica and Protorhabdonella curta were 40 and 85 times more abundant in bottle than in net samples, respectively. Such values were valid only for those samples in which these taxa occurred with densities $>0.05$ ind. $\mathrm{l}^{-1}$, and therefore they had to be recorded by the 2 sampling gears. However, they should be seen as 
overestimated in $25 \%$ of the paired samples, in which the concentrations of $A$. norvegica forma typica or $P$. curta were $<0.05$ ind. $\mathrm{l}^{-1}$ (detection limit of the bottle). Furthermore, these values $(40 \times$ for $A$. norvegica forma typica and $85 \times$ for $P$. curta) did not prove to be accurate due to the low number of paired samples analysed, and therefore they could not be used to correct net-based concentrations, preventing further comparisons between bottle and net results. They were useful only as indicators of the degree of underestimation obtained in the fraction $<40 \mu \mathrm{m}$ when assessing densities from $35 \mu \mathrm{m}$ mesh net samples. Considering the total number of tintinnids retrieved by the Niskin bottle during the paired sampling, ca. $38 \%$ corresponded to the $<40 \mu \mathrm{m}$ fraction.

\section{DISCUSSION}

\section{General overview}

Up to the present, only a few studies have undertaken comparisons among different sampling systems for tintinnids (Brownlee \& Jacobs 1987, Middlebrook et al. 1987, Pierce \& Turner 1994). The bottle and net sampling methods are routinely used in oceanographic surveys, each one having its own advantages and disadvantages: the former estimates quantitative and biomass values more precisely, while the latter produces more reliable qualitative estimates, due to the larger water volume of the samples collected (Alder 1999). This basic methodological problem must be considered in ecological studies, especially when these are aimed to compare communities, either within the same zone or among different ocean areas worldwide. In the present study, the use of the net and bottle sampling methods yielded differences in the abundance of tintinnids measuring $>40 \mu \mathrm{m}$, which were quite similar to those reported by Middlebrook et al. (1987) for materials from Fundy Bay. These authors found that the densities of tintinnid species from bottle samples were $10 \%$ higher than those from $30 \mu \mathrm{m}$ mesh nets. (All the species observed by these authors have diameters $>30 \mu \mathrm{m}$.)

According to the above considerations, the comparison between the present dataset (bottle sampling method) and that from the previous survey carried out in November 1994 (TABIA II cruise, Thompson et al. 1999; net sampling method) has some limitations. There might be a bias in tintinnid densities due to the sampling system used in 1994. Anyway, the statistical analyses performed on paired samples may allow determination of some trends concerning the structure of tintinnid communities within the 0 to $50 \mathrm{~m}$ layer over a 2 yr period and at a large spatial scale $\left(30\right.$ to $\left.60^{\circ} \mathrm{S}\right)$.
Similarities between 1994 and 1995 can be summarised as follows: first, 3 biogeographic zones occur with similar latitudinal ranges. Although the position of the fronts (Fig. 5; the Polar Front is revealed by a local drop in nutrients around 55 to $57^{\circ} \mathrm{S}$ during both cruises, while the Subtropical Front is located at $\sim 48$ to $50^{\circ} \mathrm{S}$ ) seemed to change slightly, the distance between the XBT profiles (around 2 to $4^{\circ}$ in latitude) did not denote any latitudinal variation between both years. Second, a homogeneous thermal structure (i.e. a lack of vertical stratification) occurs, as reflected by the stable composition of the tintinnid community with depth. Third, tintinnid densities and biomass values within the TZ were higher than in the SZ and AZ. Finally, mean values of diversity in the TZ, SZ and AZ were high, low and moderate, respectively.

Mean diversity values obtained herein for each biogeographic zone (see 'Results') were lower than those estimated from the 1994 dataset (specific richness: 15.5, 6.1 and 7.3; specific diversity: $1.74,0.95$ and 1.45; for $\mathrm{TZ}, \mathrm{SZ}$ and $\mathrm{AZ}$, respectively). These differences could be partially attributed to the bottle sampling method, which failed to detect taxa that occurred sporadically (around $10 \%$ of the total number of species showed concentrations $<0.05$ ind. $\mathrm{l}^{-1}$ ), and/or to the presence of a bulk of dominant species, which contributed to the decrease in specific-diversity values.

\section{The Transition Zone}

As already mentioned, the BMC is a key location within the South Atlantic Ocean, due to its dynamics and variability (e.g. large SST variations at seasonal and interannual time scales), as well as to the impact of its oceanographic processes on local and global climate. Therefore, one of the tasks of the present study was to estimate how these processes influence the distribution of tintinnid communities in the TZ.

Highest tintinnid richness and diversity values in the $\mathrm{TZ}$ resulted from the contribution of the different water masses to the area: the occurrence of warm-water, subantarctic-water, neritic and freshwater tintinnid species indicated the presence of subtropical waters from the Brazil Current, subantarctic waters from the Malvinas Current and waters from the continental shelf and the Río de la Plata, respectively. In addition, the occurrence of deep-water taxa (according to the classification of Balech 1972) in the 0 to $50 \mathrm{~m}$ layer during both cruises (Xystonellopsis spp. in 1994; Ormosella spp. in 1995 and Parundella spp. in both years) is thought to be related to an upwelling event thermally registered by the XBT profiles around $36^{\circ} \mathrm{S}$ during 1994 (Thompson et al. 1999). The fact that this phenomenon could not be detected through hydrological 

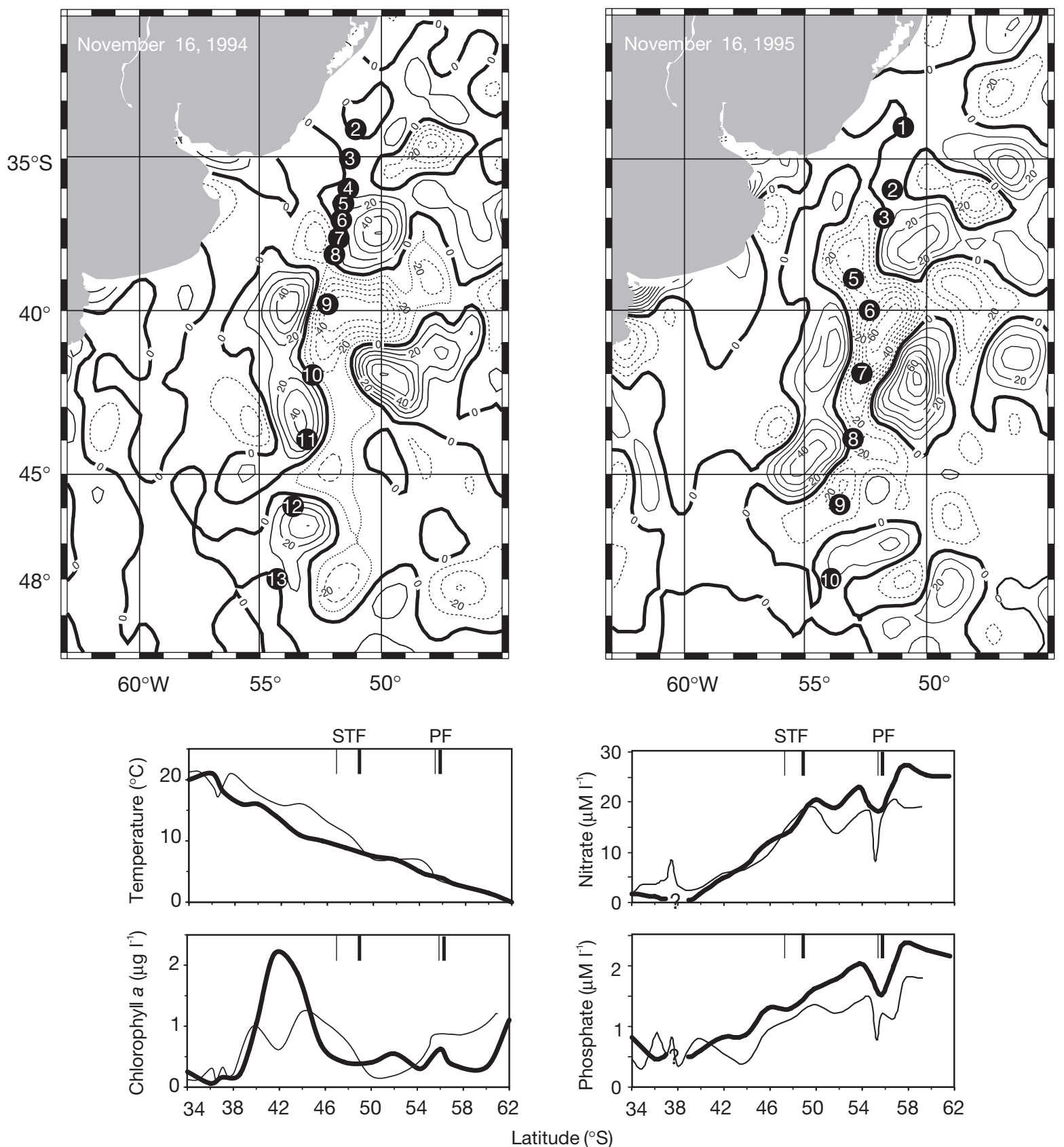

Fig. 5. Upper panels: comparison between the studied periods of the sea-surface height anomaly (the isoline interval is 10

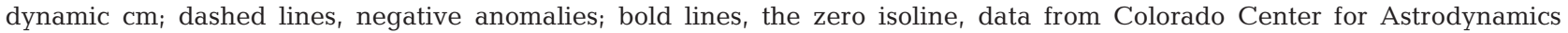
Research-Real-Time Altimetry Project, WWW homepage: http://e450.colorado.edu/realtime/gsfc_global-real-time_ssh/). Lower panels: sea-surface temperature, chlorophyll $a$, phosphate and nitrate profiles (thin line: November 1994; thick line: November 1995; STF: Subtropical Front [approx. location]; PF: Polar Front)

settings during 1995 might be due to the low resolution of the XBT profiles.

Highest chlorophyll a concentrations in the TZ (with chlorophyll a patches dominated by Acanthostomella norvegica forma typica, Protorhabdonella curta [1995] and Epiplocylis acuminata [1994]) were presumably due to the mixing of nutrient-enriched subantarctic waters with oligotrophic subtropical waters (Brandini et al. 2000). Tintinnid growth rates have been observed to increase with temperature, food availability and quality (Verity 1986a). Hence, the highest concentrations registered for the above species in the TZ would be a consequence of their rapid turnover rates, which would allow them to react swiftly to enhanced feeding 
conditions (see below: 'Predator-prey relationships'). A different scenario appears when considering the Subtropical Front: a local increase in tintinnid abundance was found for both cruises, but chlorophyll a levels remained low (Fig. 5). Such increments were likely to be associated with passive advective processes, which would result in the frontal accumulation of organisms (Olson et al. 1994).

On the other hand, the TZ showed a pronounced change in tintinnid abundances and in community structure from 1994 to 1995. Although tintinnid numbers recorded in 1995 (bottle sampling method; mean: 126 ind. $\mathrm{l}^{-1}$ ) were higher and more precise than those estimated for 1994 (net sampling method; mean: 11 ind. $\mathrm{l}^{-1}$, max.: 58.68 ind. $\mathrm{l}^{-1}$ ), methodological biases (affecting the densities of species in the $<40 \mu \mathrm{m}$ fraction; see 'Results') alone cannot account for the fact that in 1995 tintinnids were about 1 order of magnitude more abundant than in 1994. However, it should be noted that in 1995 the proportion of tintinnids having a diameter $<40 \mu \mathrm{m}(86 \%)$ was $>2$ times that obtained with the bottle sampling method during the simultaneous bottle-net sampling (only 38\%). During 1995, tintinnids $>40 \mu \mathrm{m}$ in diameter (as previously pointed out, their density in net and bottle samples did not differ statistically) were 2.6 and 6.5 times (in numbers and biomass, respectively) less abundant than during
1994 (Table 1). In addition, there were yearly differences in the structure of the tintinnid community: the subantarctic-water species Cymatocylis antarctica forma typica and Steenstrupiella pozzii were around 9.3 and 9.8 times (in numbers and biomass, respectively) more abundant in 1995 than in 1994 (Table 1), while the abundance and biomass in the comparable fraction $(>40 \mu \mathrm{m})$ of transitional and warm-water species were, respectively, 3 and 8 times higher in 1994 (Table 1). The individual biomass values of these species (e.g. Xystonella treforti, Eutintinnus medius) were higher in 1994, thus suggesting 'enhanced' environmental conditions for these organisms in that period. Cosmopolitan species registered were also more abundant during 1994 (Table 1).

These differences would be explained by a comparative analysis of the hydrological conditions during 1994 and 1995. Variations in the South Atlantic Ocean circulation patterns and in the SST can take place over different time scales and are influenced by interactions between opposite flows of the Brazil and Malvinas Currents, which, in turn, are affected by the basinscale wind field and other atmospheric features (e.g. the South Atlantic Convergence Zone, Campos et al. 1999). A detailed analysis of the SST distribution made by Boebel et al. (1999) revealed a different flow pattern for each period: in November 1994, the Brazil Current

Table 1. Mean density and biomass values of tintinnid taxa, grouped by water-type preference, in the Transition Zone during November 1994 (TABIA II cruise) and November 1995 (TABIA III cruise). In order to make these values comparable, only taxa present in the upper $50 \mathrm{~m}$ and with dimensions over $40 \mu \mathrm{m}$ are considered

\begin{tabular}{|c|c|c|c|c|c|c|}
\hline \multirow{2}{*}{$\begin{array}{l}\text { Water-type preference } \\
\text { Taxon }\end{array}$} & \multicolumn{2}{|c|}{ Density (ind. $\mathrm{l}^{-1}$ ) } & \multicolumn{2}{|c|}{ Biomass (pg C $\left.\mathrm{l}^{-1}\right)$} & \multicolumn{2}{|c|}{ 1995/1994 ratio } \\
\hline & 1995 & 1994 & 1995 & 1994 & Density & Biomass \\
\hline \multicolumn{7}{|l|}{ Warm water } \\
\hline Rhabdonella spiralis & 0.068 & 1.030 & 1.79 & 45.13 & & \\
\hline Xystonella longicauda & 0.087 & 0.730 & 1.37 & 8.48 & & \\
\hline Eutintinnus medius & 0.489 & 0.461 & 3.77 & 5.97 & & \\
\hline Xystonella treforti f. typica & 0 & 0.432 & 0 & 33.10 & & \\
\hline Rhabdonella amor var. indica & 0.418 & 0.261 & 1.22 & 0.72 & & \\
\hline Rhabdonella amor var. valdestriata & 0 & 0.313 & 0 & 7.35 & & \\
\hline Other taxa (16-TABIA II; 3 - TABIA III) & 0.067 & 0.255 & 0.37 & 4.95 & & \\
\hline \multicolumn{7}{|l|}{ Transitional (warm water) } \\
\hline Epiplocylis acuminata & 1.611 & 5.389 & 7.7 & 22.3 & & \\
\hline TOTAL & 2.740 & 8.871 & 16.22 & 128.00 & 0.31 & 0.13 \\
\hline \multicolumn{7}{|l|}{ Cosmopolitan } \\
\hline Dictyocysta mitra & 0.095 & 0.415 & 0.25 & 1.22 & & \\
\hline Dictyocysta elegans var. speciosa & 0.112 & 0.139 & 0.22 & 0.71 & & \\
\hline Dictyocysta elegans var. lepida & 0.023 & 0.216 & 0.10 & 0.91 & & \\
\hline Amphorides quadrilineata & 0.049 & 0.018 & 0.70 & 0.26 & & \\
\hline TOTAL & 0.279 & 0.788 & 1.27 & 3.10 & 0.35 & 0.41 \\
\hline \multicolumn{7}{|l|}{ Subantarctic water } \\
\hline Cymatocylis antarctica f. typica & 0.432 & 0.002 & 1.65 & 0.01 & & \\
\hline Steenstrupiella pozzii & 0.321 & 0.079 & 1.11 & 0.27 & & \\
\hline TOTAL & 0.753 & 0.081 & 2.76 & 0.28 & 9.30 & 9.86 \\
\hline ALL TAXA & 3.772 & 9.740 & 20.25 & 131.38 & 0.39 & 0.15 \\
\hline
\end{tabular}


extended beyond $44^{\circ} \mathrm{S}$ before it retroflexed to the northeast, while, during November 1995, this current protruded down to $43^{\circ} \mathrm{S}$, where it mainly retroflexed to the north. In agreement with these findings, and based on the analyses of meridional velocities, Witter \& Gordon (1999) estimated a decrease in the Brazil Current's transport relative to that of the Malvinas Current from November 1994 to November 1995. This information can also be supported by results of the latitudinal profile of SST obtained herein, which was 1 to $5^{\circ} \mathrm{C}$ lower in 1995 compared to 1994 (with a mean value of $2.4^{\circ} \mathrm{C}$; Fig. 5). It has been suggested that interannual variability in the SST along the eastern South American Continental Shelf could be related to El Niño-Southern Oscillation (ENSO, Campos et al. 1999). During the periods covered by this study, 'moderate' impacts of El Niño (1994/1995) and La Niña (1995/1996) on South American and African coasts were reported. In the latter, an anomalous warming was observed near the Equator from December 1994 on, which reached a peak in March 1995 (Gammelsrød et al. 1998). Average data from the southwestern Atlantic indicate that El Niño occurs in December and is characterised by negative SST anomalies of the Malvinas Current, and positive SST anomalies of the Brazil Current. Conversely, La Niña, induces the opposite phenomenon (Severov et al. 2004).

In addition, the comparison of satellite sea-surface height anomaly (SSHA) images showed the presence of a $>100 \mathrm{~km}$ wide band of cold-subantarctic water (negative anomalies at Stns 5 to $9 ; 38$ to $46^{\circ} \mathrm{S}$; Fig. 5) limited to November 1995. This feature has also been identified as a cold-core intrusion of cyclonic circulation (namely $C-\delta$; Boebel et al. 1999). Other variables evaluated during these periods suggest higher phytoplanktonic concentrations (a 1.5-fold increase in chlorophyll a values; Fig. 5), as well as nutrient enrichment (1.4 $\mu \mathrm{M}$ of phosphate and $15 \mu \mathrm{M}$ of nitrate during 1995 versus 0.9 and $14 \mu \mathrm{M}$ during 1994; Fig. 5). This can be mainly attributed to a stronger contribution of nutrient-enriched waters from the Malvinas Current and, to a lesser extent, from the Río de la Plata into the BMC. Río de la Plata waters were observed to increase their flow during El Niño events (Piola et al. 2004).

It should be stressed that the processes causing variability in the hydrological conditions are beyond the scope of this study. More complete and simultaneous oceanographic-atmospheric information is required for a thorough understanding of the functioning and fluctuations of a complex area such as the BMC. It should be noted, however, that the cold-core intrusion of subantarctic waters during 1995 (probably as a consequence of a relative decrease in the southward transport of the Brazil Current) favoured the contribution of subantarctic-water tintinnid taxa during that period. In contrast, a relative increase in the Brazil Current's transport during November 1994 was reflected, not only in the larger number of warm-water forms (41 versus 29), but also by the dominance in number and biomass shown by some of them (only 3 of the forms had densities below the detection limit of the bottle: 0.05 ind. $\mathrm{l}^{-1}$ ). These assertions are also valid when considering only the comparable fraction (>40 $\mu \mathrm{m}_{\text {; }}$ Table 1). The latitudinal profiles of density of the dominant species constructed for each year (Acanthostomella norvegica forma typica and Protorhabdonella curta for 1995; Epiplocylis acuminata for 1994) help to confirm the occurrence of transport fluctuations in the Brazil and Malvinas Currents, independent of the sampling method. These fluctuations strongly influenced the distribution limits of these taxa: the density values estimated for $A$. norvegica forma typica and $P$. curta were not comparable because they depended on the sampling method used. However, this fact did not affect the latitudinal trends observed for these species (Fig. 6). A. norvegica forma typica, which seemed to dominate in surface subantarctic waters, extended its spatial distribution markedly up to $38^{\circ} \mathrm{S}$ in 1995, while during the 'warm' year of 1994 it drew back approximately $1^{\circ}$ southward, and concentrated both in the vicinity of the Subtropical Front and in typical subantarctic waters (Fig. 6). The main portion of the population of $P$. curta (transitional warmwater species), which was concentrated around the Subtropical Front $\left(\sim 47^{\circ} \mathrm{S}\right)$ during 1994, was displaced to the north and disseminated between 34 and $46^{\circ} \mathrm{S}$ in 1995 (Fig. 6). The transitional warm-water species $E$. acuminata (in the $>40 \mu \mathrm{m}$ fraction) reached $46^{\circ} \mathrm{S}$ during the warm year of 1994 , but it was found only up to $44^{\circ} \mathrm{S}$ during the cold year of 1995 (Fig. 6).

According to the 1994 to 1995 comparison, the TZ hosts assemblages of species mainly composed of a mixture of foreign taxa from its surroundings, because of the interaction strength between adjacent Subtropical and Subantarctic ecological systems. At the same time, the TZ has a set of characteristics defined by space and time mesoscales. Although the presence of endemic species could not be established in the BMC, this huge area did not serve as a cemetery for subtropical and/or subantarctic species. The fluctuating hydrological mechanisms that operate in this region affect the structure of tintinnid communities, though keeping their high biomass: the more extensive the warm-water transport (1994), the greater the dominance of warm-water species and the higher the diversity. An opposite trend was found true for 1995: a decrease in the warm-water transport favoured the contribution of a few subantarctic-water species and a decrease in diversity parameters. In this context, natural hydrological disturbances resulted in a strong 

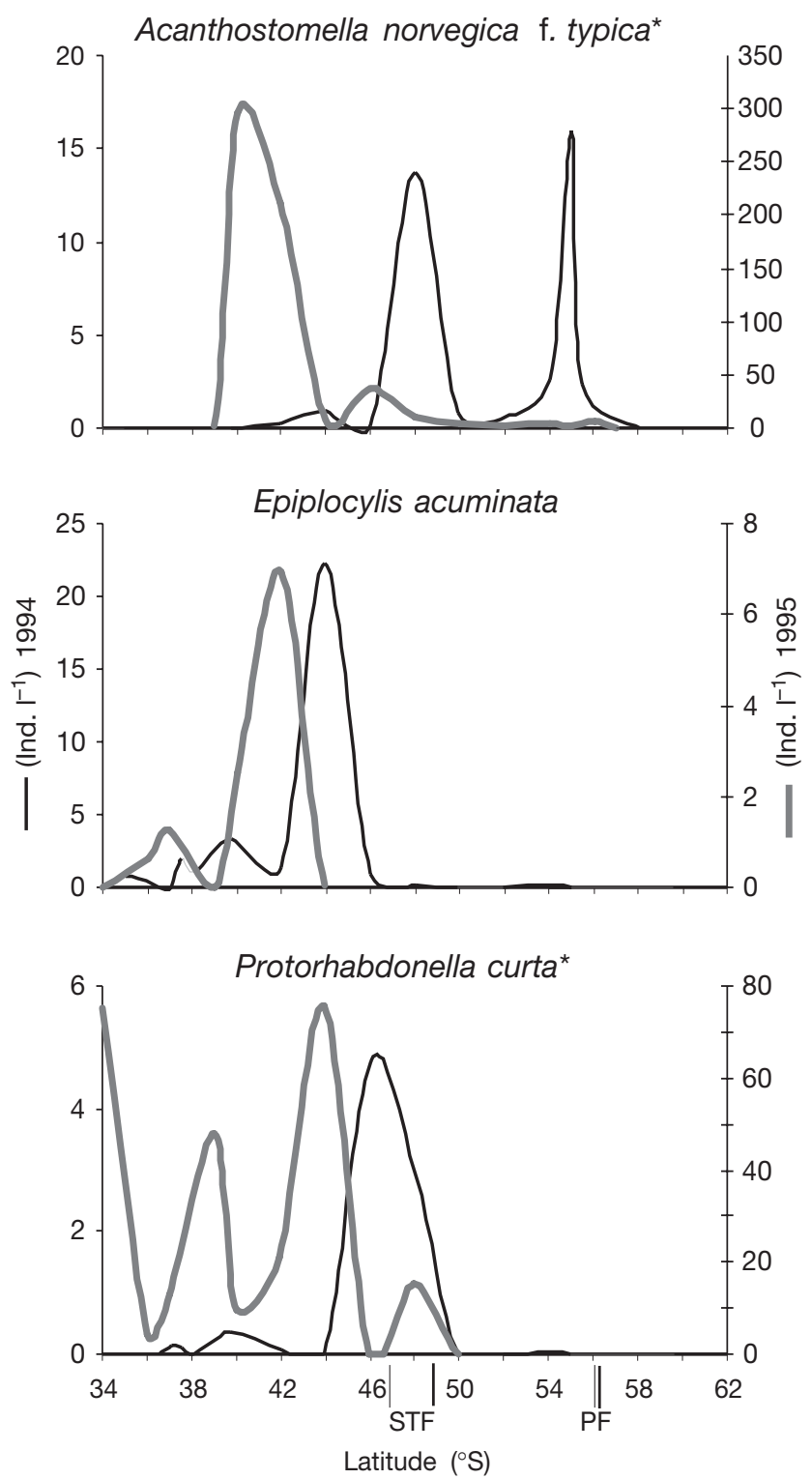

Fig. 6. Latitudinal profiles of superficial densities of Acanthostomella norvegica f. typica, Epiplocylis acuminata and Protorhabdonella curta in November 1994 (TABIA II cruise, black line) and in November 1995 (TABIA III cruise, grey line) (STF: Subtropical Front [approx. location]; PF: Polar Front; *: absolute abundance for A. norvegica f. typica and P. curta are not comparable [different scales], since they were strongly undersampled during 1994)

change in composition, but they did not affect the total biomass of the assemblage. The decrease in the concentration of subtropical species during 1995 would be compensated by an increment in subantarctic species, while mean values of biomass for 1994 and 1995 were rather similar: $0.19 \mu \mathrm{g} \mathrm{Cl}^{-1}$ in 1995 versus $0.13 \mu \mathrm{g} \mathrm{Cl}^{-1}$ in 1994. In 1995, this could be attributed to the relatively low contribution to biomass by the numerically dominant species, because of their small volume (around $1500 \mathrm{\mu m}^{3}$ per lorica). In contrast, during 1994, the subtropical species were noticeably larger (20 000 to $200000 \mu^{3}$ per lorica) and the loss of the $<40 \mu \mathrm{m}$ fraction had a lower impact on tintinnid total biomass. In agreement with Tilman (1996), the variability in species abundances should be regarded as a compensation mechanism that keeps the total community biomass almost unchanged.

\section{The Subantarctic Zone and Antarctic Zone}

The hydrological features and the dominant taxa were similar in both zones and study periods. Within the SZ, SST ranges, mean chlorophyll a values and nitrate/phosphate ratios were similar for 1994 and 1995 ( 8 to $4^{\circ} \mathrm{C}, 0.5 \mu \mathrm{g} \mathrm{l}^{-1}$ and N/P $=12$, respectively; Fig. 5), probably due to negligible changes in the oceanic circulation (low variability in SSHA, Fu 1996). This was also reflected by the weak annual SST variations (Podestá et al. 1991, Provost et al. 1992) characterising this zone. Similarities between tintinnid associations were clearly reflected in the dominant taxa (e.g. Cymatocylis antarctica forma typica and Acanthostomella norvegica forma typica), which in both study periods represented $>40$ and $70 \%$ of tintinnid cells and biomass, respectively. In the AZ, SST ranges, chlorophyll a values and nitrate/phosphate ratios registered in both periods were almost alike ( 1 to $0^{\circ} \mathrm{C}, 0.6 \mu \mathrm{g} \mathrm{l}^{-1}$ and $\mathrm{N} / \mathrm{P}=12$, respectively), and different morphotypes of Codonellopsis gaussi and Cymatocylis convallaria represented $>57 \%$ of the tintinnid cells. Tintinnid abundances were also similar in 1994 and 1995, and closely comparable to those previously reported for the region (Boltovskoy \& Alder 1992, Alder 1995, Fernandes 1998, Alder \& Thompson 2000). It should be noted that most of the species in antarctic waters were $>40 \mu \mathrm{m}$ in diameter, suggesting that the collecting methods under study had little influence on abundance estimations. $C$. antarctica forma typica and A. norvegica forma typica within the SZ, and C. gaussi and C. convallaria within the AZ have shown persistence and high densities and biomasses in comparison to the other taxa found in both zones during the 2 years covered by this study. This information is also in agreement with that obtained previously (Alder 1995, 1999, Fernandes 1999, Alder \& Thompson 2000, Thompson 2001). So, and according to the concept of Modigh \& Castaldo (2002), the above-mentioned taxa may be considered key tintinnid species for their corresponding zones, and, thus, they can be used to track changes in environmental and hydrographical settings in the oceanic SZ and AZ. 
As observed in the TZ, the total number of species differed between 1994 and 1995 in the SZ and the AZ. The taxa identified in the SZ were 12 in 1995 and 24 in 1994 (with only 10 of them being common to both years). During 1995, Dadayiella ganymedes was the single foreign species from the TZ. Conversely, in 1994, foreign species comprised several of the warmwater taxa found (Acanthostomella norvegica forma lata, Amphorides quadrilineata var. minor, Ascampbelliella acuta, Epiplocylis acuminata, Protorhabdonella curta, Rhabdonella amor var. indica, R. spiralis, Undella globosa and U. subcaudata subcaudata) along with 3 cosmopolitan species (Dictyocysta elegans var. speciosa and var. lepida and D. mitra), with concentrations $>0.05$ ind. $\mathrm{l}^{-1}$. The number of antarctic taxa in the SZ was similar for both periods (5 in 1994 vs. 3 in 1995): Codonellopsis balechi was only recorded in 1995, C. gaussi forma typica and forma cylindroconica in 1994 and 1995, and C. gaussi forma globosa and Laackmanniella naviculaefera only in 1994. Finally, a total of 5 species was registered in the AZ during 1995 and 9 species in 1994 (4 species in common). Cymatocylis calyciformis appeared only in 1995, while Cymatocylis drygalskii and Cymatocylis nobilis, together with expatriated taxa from the SZ (A. norvegica forma typica and Cymatocylis antarctica) and from the TZ (D. ganymedes) were only recorded in 1994.

The increment of expatriated taxa within the SZ and AZ would be attributable to eddy transport from the Brazil Current. Martos \& Piccolo (1988), reported a series of warm-core eddies migrating into the ACC after this current unusually retreated southward (as happened during 1994). The BMC area is also rich in eddies of varying number, size, mean lifetime and translational speed (Lentini et al. 2001). Therefore, the decline in the number of expatriated species during 1995 (also reflected in the lowest values of specific richness and biodiversity) would indicate fewer southbound eddies from the BMC into Subantarctic and Antarctic waters for this period (Gordon 1989, Alder \& Thompson 2000). This was possibly due to the relatively low southward transport of Brazil Current waters into the $\mathrm{TZ}$.

Unfortunately, it could not be confirmed if specimens collected from eddies or belonging to rare species within the $\mathrm{TZ}$ were alive at the moment of their capture. This limitation, which is common to all studies of microplanktonic shell-bearing organisms (tintinnids, radiolarians, foraminifers, diatoms, etc.), can and should be solved in future investigations by the support of in vivo observations. However, the use of the loricae alone in studies on the distribution of tintinnid species has proved to be a powerful tool for the detection and interpretation of oceanographic changes (see reviews by Pierce \& Turner 1993, Alder 1999).

\section{Predator-prey relationships}

No simultaneous information on phytoplankton size structure and composition is available for the periods under study. Nonetheless, food preferences of the dominant species within the TZ and SZ could be inferred from a work by Fernandes \& Brandini (1999) carried out during November 1992 on oceanic waters of the same area, and from data collected along Atlantic meridional transects during September and October in 1996 and 1997 to investigate the size-structure distribution of picoplankton and phytoplankton (Zubkov et al. 2000, Marañón et al. 2001).

Within the TZ, Fernandes \& Brandini (1999) documented that the nanoplanktonic Phaeocystis aff. globosa (3 to $9 \mu \mathrm{m}$ ) accounted for some peaks of chlorophyll a during 1992. For the SZ, the same authors reported that the phytoplanktonic community was dominated by the nanoplanktonic diatom Chaetoceros spp. (10 to $20 \mu \mathrm{m}$ in size). Interestingly, the size of $P$. aff. globosa and Chaetoceros spp. is about $1 / 4$ of the lorica's oral diameter of the dominant tintinnid species (Acanthostomella norvegica forma typica [mean: $26 \mu \mathrm{m}_{i}$ range: 19 to $32 \mu \mathrm{m} ; \mathrm{N}: 240$ ] and Protorhabdonella curta [mean: $29 \mu \mathrm{m}$; range: 25 to $38 \mu \mathrm{m}_{i} \mathrm{~N}$ : 144] for the TZ and Cymatocylis antarctica forma typica [mean: $50 \mu m_{i}$, range: 44 to $80 \mu m_{i}$ N: 515] for the SZ). Considering that the prey size most efficiently ingested by a tintinnid is about $25 \%$ the oral diameter of its lorica (Dolan et al. 2002), it is highly probable that these species consume nanoplanktonic components regularly, as reported by several previous studies (Verity 1987, see also review Pierce \& Turner 1992). Indeed, microzooplankton grazing rates were reported to be linearly related to nanoplankton production (Verity 1986b).

In addition, during 1995, peak concentrations of Acanthostomella norvegica were recorded in transitional waters (Figs. 2 \& 3), where the highest contribution of picoplankton to total primary production (around $40^{\circ} \mathrm{S}$; Marañón et al. 2001) and the highest concentrations of the picoplankter Synechoccocus (water temperature around $16^{\circ} \mathrm{C}$; Zubkov et al. 2000) have been observed during austral spring. Although bacterivory has been reported for several species of tintinnids (Pierce \& Turner 1992), it was concluded that these protists are subject to significant mortality when feeding only on Synechoccocus (Capriulo 1990). Recent investigations indicated that tintinnid cells contain similar quantities of algae and Synechococcus and that they regularly ingest these resources 5 times more than aloricate ciliates (Paraskevi et al. 2001). According to this, at least between 40 and $42^{\circ} \mathrm{S}, A$. norvegica may play a major role in the consumption of nanoplanktonic and picoplanktonic (Synechococcus) components. 
During the periods studied, some other microzooplanktonic components, such as foraminifers and crustacean larvae (mainly copepods), showed very low abundances (Thompson et al. 1999, Thompson 2001) and correlated very weakly with tintinnids (Table 2). Foraminifers and copepods predate, not only on phytoplankton, but also on tintinnids (Caron \& Swanberg 1990, Pierce \& Turner 1992). However, they would not be able to react rapidly to increments in tintinnid densities because of their comparatively low turnover rates (20 to $30 \mathrm{~d}$ for foraminifers and up to several months for copepods; Caron \& Swanberg 1990, Bradford-Grieve et al. 1999), as compared with the duplication times of tintinnids (on the order of hours; Heinbokel 1988). The low abundances of other microzooplanktonic predators and the recurrence and dominance of Acanthostomella norvegica and Cymatocylis antarctica in the SZ suggest that these species might play an important role in the SW Atlantic subantarctic pelagic food web by acting as a trophic link between pico-, nanoplankters and planktonic metazoans.

\section{CONCLUSIONS}

This study used a combined taxonomic, ecological and oceanographic approach, whereby microplanktonic tintinnids served as hydrological indicators to explain a number of large-scale oceanographicatmospheric processes taking place in the SW Atlantic. Such processes, which influence the local and regional diversity and the ecosystem, mainly affected the TZ. It exhibited a marked physical heterogeneity and pronounced interannual changes, mostly caused by variations in the transport of the Brazil and Malvinas Currents. These variations within the TZ are thought to be related to El Niño (1994) and La Niña (1995) events, and were observed to contribute to higher levels of biomass (as compared to the SZ), possibly due to the mixing of subtropical waters with enriched, subantarctic ones. Because this dynamic ecotone was characterised by the highest diversity values and dissimilar tintinnid species struc-

Table 2. Spearman rank correlation between tintinnid densities and concentrations of crustacean larvae and foraminifers for each cruise. The number of samples $(\mathrm{N})$, the correlation coefficient $\left(\mathrm{r}_{\mathrm{s}}\right)$ and the value of $\mathrm{p}$ (in parentheses) are indicated

\begin{tabular}{|lccccc|}
\hline Cruise & $\mathrm{N}$ & \multicolumn{3}{c}{ Crustacean larvae } & \multicolumn{2}{c|}{ Foraminifers } \\
& & $\mathrm{r}_{\mathrm{s}}$ & $(\mathrm{p})$ & $\mathrm{r}_{\mathrm{s}}$ & $(\mathrm{p})$ \\
\hline 1995 (TABIA III) & 38 & 0.41 & $(0.007)$ & 0.24 & $(0.123)$ \\
1994 (TABIA II) & 56 & 0.25 & $(0.060)$ & 0.34 & $(0.012)$ \\
\hline
\end{tabular}

tures, it should be considered as much more than an example of species expatriation.

The possible farther extent southward of the Brazil Current implies strong eddy formation and activity within the SZ and AZ, thus contributing to the expatriation of subtropical taxa within the ACC. Dominance of subantarctic species within this zone is observed during 'cold' periods. Despite the pronounced fluctuations in the oceanic conditions taking place in the $\mathrm{BMC}$, the SZ and the AZ showed low variability, as reflected by the similar tintinnid structures found and the persistence of a few (key) species. Particularly in the former zone, and during austral spring, Acanthostomella norvegica and Cymatocylis antarctica seem to be complementary taxa in the use of available ecosystem resources and are believed to play an important role as consumers of nanoplanktonic components. Because these unicellular organisms are directly influenced by environmental conditions and their distribution affects higher trophic levels, it can thus be concluded that the recorded interannual fluctuations could be extended to other communities within the TZ.

Acknowledgements. We wish to thank Dr. D. Boltovskoy and anonymous reviewers for their thoughtful comments on earlier versions of this paper. Thanks are due to crew members onboard the Brazilian research and support vessel 'Ary Rongel' for logistic and technical assistance, and in particular to Dr. F. Brandini, chief PI of the TABIA project. This work was partially financed by grants from the Consejo Nacional de Investigaciones Científicas y Técnicas (CONICET PIP 4159/97 and 2223/00) and the Universidad of Buenos Aires (UBA TX-084). G.A.T. was supported by a scholarship of CONICET (Argentina), and V.A.A. by Instituto Antártico Argentino (Project No. 58) and Agencia Nacional de Promoción Científica y Tecnológica (PICT 7-9108).

\section{LITERATURE CITED}

Abboud-Abi Saab M (1989) Distribution and ecology of tintinnids in the plankton of Lebanese coastal waters (eastern Mediterranean). J Plankton Res 11:203-222

Alder VA (1995) Ecología y sistemática de Tintinnina (Protozoa, Ciliata) y microzoopláncteres asociados de aguas antárticas. PhD thesis, Universidad Buenos Aires

Alder VA (1999) Tintinnoinea. In: Boltovskoy D (ed) South Atlantic zooplankton. Backhuys, Leiden, p 321-384

Alder VA, Thompson GA (2000) Spatial and temporal distribution of tintinnids (Protozoa, Ciliata) in relation to frontal systems and the general hydrologic dynamics of the Southern Ocean (SW Atlantic Sector; $50^{\circ}-64^{\circ} \mathrm{S}$, $65^{\circ}-49^{\circ} \mathrm{W}$ ). In: Davidson W, Howard-Williams C, Broady P (eds) Antarctic ecosystems: models for wider ecological understanding. New Zealand Natural Sciences, Canterbury University, Christchurch, p 203-214

Balech E (1972) Los tintínidos indicadores de afloramientos de aguas (Ciliata). Physis 31:519-528

Boebel O, Schmid C, Podestá G, Zenk W (1999) Intermediate water in the Brazil-Malvinas Confluence Zone: a Langrangian view. J Geophys Res 104(C9):21063-21082 
Boltovskoy D, Alder VA (1992) Microzooplankton and tintinnid species-specific assemblage structures: patterns of distribution and year-to-year variations in the Weddell Sea (Antarctica). J Plankton Res 14:1405-1423

Boltovskoy E, Boltovskoy D, Correa N, Brandini F (1996) Planktonic Foraminifera from the southwestern Atlantic $\left(30^{\circ}-60^{\circ} \mathrm{S}\right)$ : species-specific patterns in the upper $50 \mathrm{~m}$. Mar Micropaleontol 28:53-72

Bradford-Grieve JM, Markhaseva EL, Rocha CEF, Abiahy B (1999) Copepoda. In: Boltovskoy D (ed) South Atlantic zooplankton. Backhuys, Leiden, p 869-1098

Brandini FP, Boltovskoy D, Piola A, Kocmur S, Röttgers R, Abreu PC, Lopes RM (2000) Multiannual trends in fronts and distribution of nutrients and chlorophyll in the southwestern Atlantic (30-62 ${ }^{\circ}$ S). Deep-Sea Res I 47:1015-1033

Brownlee DC, Jacobs F (1987) Mesozooplankton and microzooplankton in the Chesapeake Bay. In: Majumdar SK, Hall Jr LW, Austin HM (eds) Contaminants: problems and management of living Chesapeake Bay resources. Pennsylvania Academy of Sciences, Easton, p 217-269

Campos EJD, Busalacchi A, Garzoli S, Lutjeharms J and 6 others (1999) The South Atlantic and the climate. OCEANOBS99: International Conference on the Ocean Observing System for Climate, Saint Raphael, France, October 18-22, 1999. Centre National d'Etudes Spatiales, Vol 1

Capriulo GM (1990) Feeding-related ecology of marine Protozoa. In: Capriulo GM (ed) Ecology of marine Protozoa. Oxford University Press, New York, p 189-259

Caron DA, Swanberg NR (1990) The ecology of planktonic sarcodines. Aquat Sci 3:147-180

Chelton DB, Schlax MG, Witter DL, Richman JG (1990) Geosat altimer observations of the surface circulation of the Southern Ocean. J Geophys Res 95:17877-17903

Dodson AN, Thomas WH (1978) Reverse filtration. In: Sournia A (ed) Phytoplankton manual. United Nations Educational, Scientific and Cultural Organization, Paris, p 104-107

Dolan JR, Claustre H, Carlotti F, Plounevez S, Moutin T (2002) Microzooplankton diversity: relationship of tintinnid ciliates with resources, competitors and predators from the Atlantic coast of Morocco to the eastern Mediterranean. Deep-Sea Res I 49:1217-1232

Evans CA, O'Reilly JE (1983) A handbook for the measurements of chlorophyll $a$ in netplankton and nanoplankton. BIOMASS Handbook 9. SCAR, Cambridge, p 1-44

Fernandes LF (1998) Taxonomia, distribuição e biomassa dos tintínidos (Protozoa-Ciliophora-Subordem Tintinnina), e microplâncton associado, entre o Rio de Janeiro e a Peninsula Antártica. PhD thesis, Universidade Federal do Paraná, Paraná

Fernandes LF (1999) Tintininos (Ciliophora-Subordem Tintinnina) de águas subantárticas e antárticas entre a Argentina e a Península Antártica $\left(35^{\circ} \mathrm{S}-62^{\circ} \mathrm{S}\right)$ (Novembro de 1992). Rev Bras Oceanogr 47:155-171

Fernandes LF, Brandini FP (1999) Comunidades microplanctônicas no Oceano Atlântico Sul Occidental: biomassa e distribuição em novembro de 1992. Rev Bras Oceanogr 47 : 189-205

Fu LL (1996) The circulation and its variability of the South Atlantic Ocean: first results from the TOPEX/POSEIDON mission. In: Wefer G, Berger WH, Siedler G, Webb DJ (eds) The South Atlantic: present and past circulation. Springer-Verlag, Berlin, p 63-82

Gammelsrød T, Bartholomae CH, Boyer DC, Filipe VLL, O'Toole MJ (1998) Intrusion of warm surface layers along the Angolan-Namibian coast in February-March 1995: the 1995 Benguela Niño. S Afr Mar Sci 19:41-56

Garzoli SL, Garraffo Z (1989) Transports, frontal motions and eddies at the Brazil-Malvinas Confluence as revealed by inverted echo sounders. Deep-Sea Res I 36:681-703

Gaston KJ (2000) Global patterns in biodiversity. Nature 405: $220-227$

Godhantaraman N (2002) Seasonal variations in species composition, abundance, biomass and estimated production rates of tintinnids at tropical estuarine and mangrove waters, Parangipettai, southeast coast of India. J Mar Syst 36:16-171

Goni G, Kamholz S, Garzoli S, Olson D (1996) Dynamics of the Brazil-Malvinas Confluence based on inverted echo sounders and altimetry. J Geophys Res 101:16273-16289

Gordon AL (1989) Brazil-Malvinas confluence - 1984. DeepSea Res I 36:359-384

Heinbokel JF (1988) Reproductive rates and periodicities of oceanic tintinnine ciliates. Mar Ecol Prog Ser 47:239-248

Ikeda Y, Siedler G, Zwierz M (1989) On the variability of Southern Ocean Front location between southern Brazil and the Antarctic Peninsula. J Geophys Res 94(C4): 4757-4762

Kamiyama T, Tsujino M (1996) Seasonal variation in the species composition of tintinnid ciliates in Hiroshima Bay, the Seto Inland Sea of Japan. J Plankton Res 18:2313-2327

Laval-Peuto M (1994) Classe des Oligotrichea Bütschli, 1887: ordre des Tintinnida Kofoid et Campbell, 1929. In: de Puytorac P (ed) Traité de zoologie. II. Infusoires Ciliés. Masson, Paris, p 181-219

Legeckis R, Gordon AL (1982) Satellite observations of the Brazil and Falkland currents-1975 to 1976 and 1978. Deep-Sea Res I 29:375-401

Lentini CAD, Podesta GG, Campos EJD, Olson DB (2001) Sea surface temperature anomalies on the western South Atlantic from 1982-1994. Cont Shelf Res 21:89-112

Lindley JA (1975) Continuous plankton records: a plankton atlas of the North Atlantic and North Sea. Suppl 3. Tintinnida (Protozoa, Ciliophora) in 1965. Bull Mar Ecol 8: 201-213

Marañón E, Holligan PM, Barciela R, González N, Mouriño B, Pazó MJ, Varela M (2001) Patterns of phytoplankton sizestructure and productivity in contrasting open ocean environments. Mar Ecol Prog Ser 216:43-56

Martos P, Piccolo MC (1988) Hydrography of the Argentine continental shelf between $38^{\circ}$ and $42^{\circ} \mathrm{S}$. Cont Shelf Res 8: 1043-1056

Middlebrook K, Emerson CW, Roff JC, Lynn DH (1987) Distribution and abundance of tintinnids in the Quoddy Region of the Bay of Fundy. Can J Zool 65:594-601

Modigh M, Castaldo S (2002) Variability and persistence in tintinnid assemblages at a Mediterranean coastal site. Aquat Microb Ecol 28:299-311

Olson DB, Podestá GP, Evans RH, Brown OB (1988) Temporal variations in the separation of Brazil and Malvinas currents. Deep-Sea Res I 35:1971-1990

Olson DB, Hitchcock GL, Mariano AJ, Ashjian CJ, Peng G, Nero RW, Podestá GP (1994) Life on the edge: marine life and fronts. Oceanography 7(2):52-60

Paranjape MA, Gold K (1982) Cultivation of marine pelagic Protozoa. Ann Inst Oceanogr Paris 58:143-150

Paraskevi P, Giannakourou A, Christaki U (2001) Planktonic ciliates in the oligotrophic Mediterranean Sea: longitudinal trends of standing stocks, distributions and analysis of food vacuole contents. Aquat Microb Ecol 24:297-311

Peterson RG, Stramma L (1991) Upper-level circulation in the South Atlantic Ocean. Prog Oceanogr 26:1-73

Pielou EC (1969) An introduction to mathematical ecology. 
John Wiley, New York

Pierce RW, Turner JT (1992) Ecology of planktonic ciliates in marine food webs. Rev Aquat Sci 6:139-181

Pierce RW, Turner JT (1993) Global biogeography of marine tintinnids. Mar Ecol Prog Ser 94:11-26

Pierce RW, Turner JT (1994) Plankton studies in Buzzards Bay, Massachusetts, USA. IV. Tintinnids, 1987 to 1988. Mar Ecol Prog Ser 112:235-240

Piola AR, Möller Jr OO, Palma ED (2004) El impacto del Plata sobre el Océano Atlántico. Ciencia Hoy 14:28-37

Podestá GP, Brown B, Evans RH (1991) The annual cycle of satellite derived sea surface temperature in the southwestern Atlantic. J Climatol 4:457-467

Provost C, Garcia O, Garçon V (1992) Analysis of satellite sea surface temperature time series in the Brazil-Malvinas Confluence region: dominance of the annual and semiannual periods. J Geophys Res 97:17841-17858

Provost C, Gana S, Garçon V, Maamaatuaiahutapu K, England $M$ (1995) Hydrographic conditions in the BrazilMalvinas Confluence during austral summer 1990. J Geophys Res 100(C6):10655-10678

Romesburg HC (1984) Cluster analysis for researchers. Lifetime Learning Publications, Belmont

Severov DN, Mordecki E, Pshennikov VA (2004) SST anomaly variability in southwestern Atlantic and El Niño/ Southern Oscillation. Adv Space Res 33:343-347

Shannon CE, Weaver W (1949) The mathematical theory of communication. University of Illinois Press, Urbana

Sokal RR, Rohlf FJ (1995) Biometry: the principles and practice of statistics in biological research. WH Freeman, New York

Strickland JDH, Parsons TR (1972) A practical handbook of seawater analysis. J Fish Res Board Can 167:1-310

Taniguchi A (1983) Microzooplankton distribution along a transverse section crossing a marked oceanic front. La Mer 21:95-101

Thompson GA (2001) Distribución y abundancia del microzooplancton en el Atlántico Sudoccidental, con especial énfasis en la biogeografía de Tintinnina (Protozoa: Ciliata). PhD thesis, Universidad Buenos Aires
Thompson GA, Alder VA, Boltovskoy D, Brandini F (1999) Abundance and biogeography of tintinnids (Ciliophora) and associated microzooplankton in the southwestern Atlantic Ocean. J Plankton Res 21:1265-1298

Tilman D (1996) Biodiversity: population versus ecosystem stability. Ecology 77:350-363

Tilman D (1999) Ecological consequences of biodiversity: a search for general principles. Ecology 80:1455-1474

Urrutxurtu I (2004) Seasonal succession of tintinnids in the Nervión River estuary, Basque Country, Spain. J Plankton Res 26:307-314

Verity PG (1986a) Growth rates of natural tintinnid populations in Narragansett Bay. Mar Ecol Prog Ser 29:117-126

Verity PG (1986b) Grazing on phototrophic nanoplankton by microzooplankton in Narragansett Bay, Rhode Island. Mar Ecol Prog Ser 29:105-115

Verity PG (1987) Abundance, community composition, size distribution, and production rates of tintinnids in Narragansett Bay, Rhode Island. Estuar Coast Shelf Sci 24: 671-690

Verity PG, Langdon C (1984) Relationship between lorica volume, carbon, nitrogen and ATP content of tintinnids in Narragansett Bay. J Plankton Res 6:859-868

Willson HR, Rees NW (2000) Classification of mesoscale features in the Brazil-Falkland Current Confluence Zone. Prog Oceanogr 45:415426

Witter DL, Gordon AL (1999) Interannual variability of South Atlantic circulation from 4 years of TOPEX/POSEIDON satellite altimeter observations. J Geophys Res 104(C9): 20927-20948

Zeitzschel B (1966) Die Verbreitung der Tintinnen im Nordatlantik. Veroeff Inst Meeresforsch 2:293-300

Zeitzschel B (1990) Zoogeography of marine Protozoa: an overview emphasizing distribution of planktonic forms. In: Capriulo GM (ed) Ecology of marine Protozoa. Oxford University Press, New York, p 139-185

Zubkov MV, Sleigh MA, Burkill PH (2000) Assaying picoplankton distribution by flow cytometry of underway samples collected along a meridional transect across the Atlantic Ocean. Aquat Microb Ecol 21:13-20 
Appendix 1. Species list and general abundance data. Numbers after species names indicate mean and [maximum] values (ind. $\mathrm{l}^{-1}$ water filtered for the entire area of study), station numbers where the taxon was recorded, and water-type preference (according to Thompson 2001) (a: antarctic waters; s: subantarctic water; w: warm water; +: Brazil-Malvinas Confluence; n: no preference [including cosmopolitan, neritic and deep-water forms]). Species and genera of dubious validity (according to Alder 1999) are denoted with an asterisk and a question mark, respectively

Acanthostomella norvegica (Daday, 1887) forma typica: $38.78[439.69] ; 3,5-15, \mathrm{~s}$

Acanthostomella norvegica forma lata (Kofoid and Campbell, 1929): 0.87 [16.03]; $6-8, \mathrm{w}$

Acanthostomella sp.: 0.05 [1.70]; 6, 7

Amphorides amphora (Claparède and Lachmann, 1858): $0.003[0.11] ; 1, w$

Amphorides quadrilineata (Claparède and Lachmann, 1858): 0.07 [0.44]; 8, 10, 12-15, $\mathrm{n}$

Amphorides quadrilineata var. minor Jörgensen, 1924: 2.68 [44.88]; 1-3, 5-7, w

*Ascampbelliella armilla (Kofoid and Campbell, 1929): 0.27 [3.66]; $1-3,5,8,10, \mathrm{w}$

*Ascampbelliella protuberans (Kofoid and Campbell, 1929): 0.25 [3.32]; $1-3,5,6,8, \mathrm{w}$

*Ascampbelliella urceolata (Ostenfeld, 1899): 0.49 [10.20]; $1-3,5,7,9$, w

Canthariella sp. (Kofoid and Campbell, 1929): 0.12 [3.41]; $6-8, \mathrm{w}$

Climacocylis scalaroides marshallae Campbell, 1942: 0.12 [2.08]; 1-3, 5, w

* Codonella aspera Kofoid and Campbell, 1929: 0.009 [0.36]; 7, w

Codonellopsis balechi Hada, 1970: 0.001 [0.06]; 14, a

Codonellopsis gaussi (Laackmann, 1907) forma typica: 0.04 [0.94]; 13, 16, a

Codonellopsis gaussi (Laackmann, 1907) forma cylindroconica: 0.003 [0.07]; 12, 13, a

Codonellopsis gaussi (Laackmann, 1907) forma globosa: $0.07[1.56]_{i} 16$, a

Codonellopsis pusilla (Cleve, 1900): 0.28 [2.91]; 6-11, 14, 15, $\mathrm{s}$

Cymatocylis antarctica (Cleve, 1901) forma typica: 8.93 [134.81]; 8, 10-15, s

Cymatocylis antarctica (Cleve, 1901) forma coxliella: 0.04 [1.13]; 11, s

Cymatocylis calyciformis (Laackmann, 1907): 0.001 [0.056]; 16 , a

Cymatocylis convallaria forma typica Laackmann, 1910: $0.02[0.5] ; 16,19$, a

Cymatocylis convallaria forma affinis Laackmann, 1910: $0.001[0.06] ; 18$, a

Cymatocylis vanhoffeni forma flava Laackmann, 1910: 0.004 [0.11]; 16, a

Dadayiella ganymedes (Entz Sr., 1884): 0.165 [1.71]; 1-3, $5-7,14, \mathrm{w}$

Dictyocysta elegans var. lepida (Ehrenberg, 1854): 0.01 $[0.57] ; 6, \mathrm{n}$

Dictyocysta elegans var. speciosa Jörgensen, 1924: 0.05 $[0.73] ; 3,7,10, \mathrm{n}$

Dictyocysta mitra Haeckel, 1873: 0.03 [0.57]; 13, 6, n Epiplocylis acuminata (Daday, 1887) forma typica: 0.72
[7.96]; 2, 3, 5-8, w+

Epiplocylis acuminata (Daday, 1887) forma coxliella: 0.03 $[0.57] ; 3,6,7, \mathrm{w}+$

*Eutintinnus apertus (Kofoid and Campbell, 1929): 0.26 [7.22]; 1, 2, 10, w

Eutintinnus medius (Kofoid and Campbell, 1929): 0.16 $[2.49] ; 13,5, \mathrm{w}$

Eutintinnus sp.: $0.03[0.46] ; 2,3,5$

Helicostomella subulata Jörgensen, 1924: 0.003 [0.13]; 2, n

Laackmanniella naviculaefera (Laackmann, 1910) forma prolongata: $0.03[0.94] ; 16$, a

Ormosella acantharus (Kofoid and Campbell, 1929): 0.011 [0.43]; 8, 13, n

Parundella caudata (Ostenfeld, 1899): 0.05 [1.09]; 2, 6, 7, 13, 15, $\mathrm{n}$

Protorhabdonella? curta (Cleve, 1900): 16.28 [142.34]; 1-3, $5-10, \mathrm{w}+$

Protorhabdonella? simplex (Cleve, 1901): 1.94 [52.45]; 3, $5-8, \mathrm{w}+$

${ }^{*}$ Rhabdonella amor var. indica Laackmann, 1910: 0.26 [5.69]; 2, 3, 6-8, w

Rhabdonella amor (Cleve, 1900) forma coxliella: 0.01 [0.57]; $6, \mathrm{n}$

${ }^{*}$ Rhabdonella cornucopia Kofoid and Campbell, 1929: 0.007 [0.31]; 3, w

Rhabdonella spiralis (Fol, 1881): 0.01 [0.61]; 1, w

Rhabdonella sp.: 0.01 [0.57]; 6

Salpingella acuminata var. glockentoegeri Brandt, 1906: $0.001[0.06] ; 1, \mathrm{w}$

Salpingella acuminata var. secata Brandt, 1906: 0.03 [0.73]; 1, 7, w

Salpingella acuminata var. undata Jörgensen, 1899: 0.001 [0.06]; $1, \mathrm{w}$

Salpingella acuminatoides (Laackmann, 1910): 0.001 [0.06]; $1, \mathrm{w}$

Salpingella sp.: 0.02 [0.73]; 7

Steenstrupiella pozzii Balech, 1942: 0.23 [3.44]; 8, 10, 13-15, $\mathrm{S}$

Steenstrupiella steenstrupii (Claparède and Lachmann, 1858): 1.69 [48.91]; 1-3, 5-7, w

Tintinnopsis brasiliensis Kofoid and Campbell, 1929: 0.005 [0.22]; $1, \mathrm{n}$

Tintinnopsis parva Merkle, 1909: 0.003 [0.11]; 1, n

Tintinnopsis sp. A: $0.001[0.06] ; 1, \mathrm{n}$

Tintinnopsis sp. B: 0.02 [0.415]; 1, 2, 5, n

Undella claparedei (Entz Sr., 1885): 0.12 [2.56]; 8, 10, w

Undella globosa (Brandt, 1906): 0.02 [0.44]; 1, 3, 8, 9, w

Undella subacuta (Cleve, 1901): 0.007 [0.31]; 3, w

Undella subcaudata subcaudata (Jörgensen, 1924): 0.06

[1.70]; $2,3,5,8, \mathrm{w}$

Undella sp.: 0.06 [2.19]; 2, 7, 10

Xystonella longicauda (Brandt, 1906): 0.02 [0.52]; 13, w 